Int. Agrophys., 2021, 35, 209-219

INTERNATIONAL

\title{
Variability of soil thermal properties along a catena in Middle Tennessee, USA **
}

\author{
Brendan Mitchell-Fostyk, Samuel Haruna®* Kevin Downs $(1)$ \\ School of Agriculture, Middle Tennessee State University, 37132, Murfreesboro, United States \\ Received March 29, 2021; accepted July 08, 2021
}

\begin{abstract}
Characterizing the spatial variability of soil thermal properties is an important component of precision agriculture. The current study characterized the spatial variability of soil thermal properties across five slope positions: summit, shoulderslope, backslope, footslope, and toeslope. Triplicate soil samples $(0-18 \mathrm{~cm})$ were collected from each slope position from a pasture field planted with tall fescue (Festuca arundinacea syn. sychedonorus arundinaceus). Soil thermal properties (thermal conductivity, volumetric heat capacity, thermal diffusivity), volumetric water content (at 0 and $-33 \mathrm{kPa}$ soil water matric potentials), bulk density, and soil organic carbon were determined. The results showed that soil organic carbon was $26 \%$ higher, while $\rho b$ was $10 \%$ lower at the toe slope as compared with the summit due to depositional forces. At saturation, volumetric heat capacity was $5 \%$ higher at the toe slope as compared with the summit which is consistent with the soil organic carbon and volumetric water content results. Semivariogram analysis showed that at saturation, the spherical isotropic models provided the best fit for soil thermal properties $\left(\mathrm{R}^{2}=0.95\right)$. The foot and toe slope positions exhibited the least variability in terms of soil thermal properties. Future studies should explore the influence of a combination of slope position and various cropping systems on soil thermal properties.

Keywords: volumetric heat capacity, thermal diffusivity, fractal dimension, soil organic carbon, thermal conductivity
\end{abstract}

*Corresponding author e-mail: Samuel.Haruna@mtsu.edu

**This work was supported Middle Tennessee State University Faculty Research and Creative Activity Grant. Index Number: $221771(11 / 2020-12 / 2021)$.

\section{INTRODUCTION}

Depositional and post-depositional processes can cause variability in soil properties, even within homogenous soil layers (Lacasse and Nadim, 1996) and this can play a major role in crop productivity. Spatial variability studies are important in predicting the influence of natural and anthropogenic factors on soil properties and in characterizing the specific ecosystem functions of soils (Kosmas et al., 2000). Spatial variability information leads to better management practices aimed at maintaining and improving the sustainability of crop production systems (Ozgoz, 2009).

Due to spatial autocorrelation (Oliver, 1987), it is important to study the structure of any population using approaches developed in Geostatistics (Isaaks and Srivastava, 1989; Cressie, 1991). These approaches involve spatial modelling (variography), spatial interpolation (kriging and other methods) and fractal characterization. This approach has been used by several authors to report spatial and fractal variability in soil physical, chemical and biological properties (e.g. Robinson and Metternicht, 2006; Fu et al., 2010; Haruna and Nkongolo, 2013; Bogunovic et al., 2014; Haruna and Nkongolo, 2014; Yang et al., 2016; Bogunovic et al., 2017; Fabijanczyk and Zawadzki, 2017; Usowicz and Lipiec, 2021).

(C) 2021 Institute of Agrophysics, Polish Academy of Sciences (c) (1) (3) $\Theta$ 
Fractals arise from different sources and have been observed in nature. Fractal dimension $\left(\mathrm{F}_{\mathrm{D}}\right)$ is a statistical index of complexity that compares how the detail in a pattern changes over the scale at which it is measured (Kenneth, 2003). Thus, $F_{D}$ may be used to indicate if, at the smallest possible scale, variabilities in investigated soil properties can be determined through length, area, or volume measurements. Most phenomena with long-range variations would have an $F_{D}$ value tending towards 1 as the observation variance would change with sampling distance (lag). It would be better to define variabilities in such properties by length. Fractals can also fluctuate between 2 and 3, with the former representing an area and the latter representing a volume measurement (Burrough, 1981). As such, fractals are important tools in understandingthe minute and sensitive variabilities in soils. Fractals have been used previously to characterize soil parameters (e.g. Burrough, 1981; Perfect and Kay, 1995; Eghball et al., 1997; Usowicz, 1999). However, fractals have not been used to describe soil thermal properties.

Soil thermal properties influence water movement and storage, nutrient availability, seed germination, and microbial activity (Shukla, 2014). Soil thermal properties can be evaluated through the measurement of thermal conductivity $(\lambda)$, volumetric heat capacity $(C)$, and thermal diffusivity (D). These properties may be influenced by anthropogenic processes like tillage and cover cropping (Haruna et al., 2017). Several researchers have reported the influence of texture and management practices on soil thermal properties (e.g. Abu-Hamdeh and Reeder, 2000; Ochsner et al., 2001; Lipiec and Usowicz, 2007; Adhikari et al., 2014; Haruna et al., 2017; Sindelar et al., 2019; Haruna, 2019). In addition, soil thermal properties may be influenced by pedogenic factors like topography and landscape position, factors that influence water content, soil organic carbon (SOC), and soil depth (Mulla and McBratney, 2002).

Currently, there are few studies onconcerning the variability of soil thermal properties in cultivated fields (e.g. Usowicz, et al., 1996; Usowicz et al., 2017; Gamage et al., 2019). However, spatial variability and fractal characterization studies along a catena are rare. This information is important since it can influence management decisions at various landscape positions in a changing global climate. Due to differences in soil properties that influence thermal properties (Bristow, 2002), soil thermal properties are hypothesized to vary across the catena. The objectives of the current study were to a) evaluate the spatial variability of soil thermal properties across several slope positions, and b) use fractal theory to assess thermal properties across several slope positions.

\section{MATERIALS AND METHODS}

The experiment was conducted at the Middle Tennessee State University Farm in Murfreesboro, TN (35.891103 N, $-86.267280 \mathrm{~W}$, average elevation $-191 \mathrm{~m}$ above sea level), with a total area of $177 \mathrm{ha}$. The majority (87\%) of soils in the study area are classified (USDA) as Typic Paleudalfs, with some Rhodic Paleudalfs (Soil Survey Staff). Five south-facing slope positions were identified in three different fields (Table 1, Fig. 1). Each field measured $181 \mathrm{~m} \mathrm{x} 60 \mathrm{~m}$. Tall fescue (Festuca arundinacea syn. sychedonorus arundinace$u s$ ) was planted in all fields and cut for hay production. The climate of the study area is Humid Subtropical. The mean 30 -year annual temperature is $14.6^{\circ} \mathrm{C}$, with the months of January $\left(-3.7^{\circ} \mathrm{C}\right)$ and August $\left(32.3^{\circ} \mathrm{C}\right)$ being the coldest and warmest months, respectively. The mean precipitation over the last three decades was $1357 \mathrm{~mm}$, with the months of May $(139 \mathrm{~mm})$ and October $(85 \mathrm{~mm})$ recording the highest and lowest precipitation, respectively.

Table 1. Selected soil properties and slope components at the various landscape positions within the study site

\begin{tabular}{lccccc}
\hline Slope positions & $\begin{array}{c}\text { Slope } \\
(\mathbf{\%})\end{array}$ & $\begin{array}{c}\text { Slope } \\
\text { shape }\end{array}$ & $\begin{array}{c}\text { Sand } \\
(\%)\end{array}$ & $\begin{array}{c}\text { Silt } \\
(\%)\end{array}$ & $\begin{array}{c}\text { Clay } \\
(\%)\end{array}$ \\
\hline Summit & 2 & Linear & 55.00 & 24.44 & 20.56 \\
Shoulderslope & 9 & Convex & 55.56 & 28.89 & 15.56 \\
Backslope & 14 & Linear & 53.33 & 29.44 & 17.22 \\
Footslope & 5 & Concave & 58.33 & 25.56 & 16.11 \\
Toeslope & 2 & Linear & 55.00 & 23.89 & 21.11 \\
\hline
\end{tabular}

a)

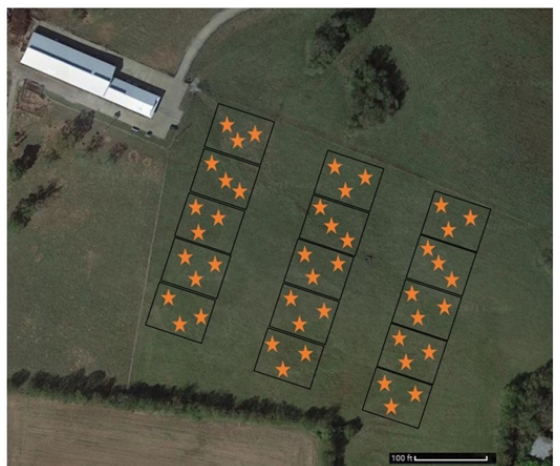

b)

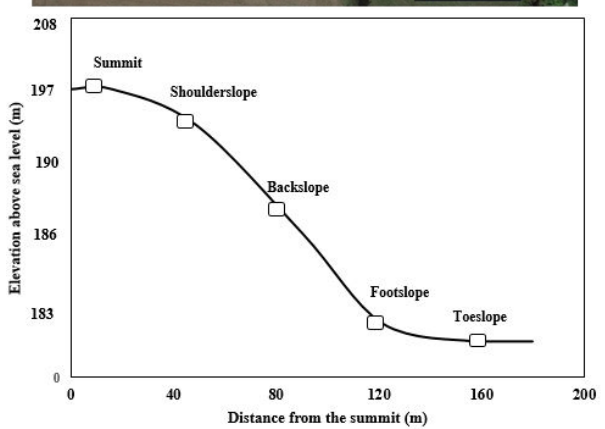

Fig. 1. a) Study site showing the sample points. Please note that the orange stars represent the approximate sample location/points, b) schematic of the cross-sectional area of the landscape.

The study area was divided into a regular grid with each box within the grid measuring approximately $12 \mathrm{~m} \times 12 \mathrm{~m}$. Soil samples were collected from each grid subsection. A trimble Geo 7 x GPS with an accuracy of $10 \mathrm{~cm}$ was used to record the georeferenced coordinates. The field area is under perennial grass management with very little human influence. The soil samples were collected at $0-18 \mathrm{~cm}$ depth 
because the fields were under perennial grass management with very little human influence. Triplicate soil samples were collected from the three adjacent fields in a cylindrical soil core $\left(\right.$ volume $\left.=508.9 \mathrm{~cm}^{3}\right)$ using an Uhland soil sampler (Uhland, 1950) in June 2019 (3 samples x 3 different fields x 5 slope positions $=45$ samples). The soil samples were trimmed, covered at both ends with a plastic cap and transported to the laboratory. They were refrigerated at $4^{\circ} \mathrm{C}$ until the time of analysis.

After the soil cores were removed from the refrigerator, the plastic caps were gently removed. The bottom of each soil core was secured using a cheesecloth and rubber bands. They were placed in a tub and saturated with tap water from the bottom up for about $24 \mathrm{~h}$ by gently raising the water level. The electrical conductivity of the water was $0.3 \mathrm{dS} \mathrm{m}^{-1}$ at $20^{\circ} \mathrm{C}$. After saturation, the soil samples were weighed, placed on pressure plates, and equilibrated to $-33 \mathrm{kPa}$ of pressure (Dane and Hopmans, 2002). After equilibration, the soil samples were weighed and the volumetric water content $(\theta)$ was determined for that pressure.

The soil thermal properties were measured using a KD2 (Decagon Devices, Pullman, WA) dual-probe heat-pulse sensor. This sensor has been used by several researchers in the past (e.g. Dahiya, et al., 2007; Adhikari et al., 2014; Haruna et al., 2017; Zaibon et al., 2019). Before measurement, the probe was calibrated and its accuracy was tested using performance verification standards. The soil thermal properties were measured at each pressure $(0$ and $-33 \mathrm{kPa})$ by vertically inserting the probe into the soil. In order to avoid errors in measurement due to improper soil contact, the probe was inserted into new areas during each measurement and core walls were avoided.

After the $\theta$ and thermal properties were measured, the soil was oven-dried at $105^{\circ} \mathrm{C}$ and the bulk density $(\rho b)$ was measured using the core method (Grossman and Reinsch, 2002). The soil was then ground and passed through a 2-mm sieve. Twenty grams of the $\leq 2 \mathrm{~mm}$ aggregates were used for to conduct a soil particle size analysis using the sedimentation method (Gee and Or, 2002). Another $50 \mathrm{~g}$ of the $\leq 2 \mathrm{~mm}$ aggregate was used for SOC determination using combustion analysis (loss on ignition at $360^{\circ} \mathrm{C}$ ) (Schulte and Hopkins, 1996).

Statistical analysis (SA) was conducted with respect to moments at each slope position in SAS ver. 9.4 (SAS Institute, 2013). Normality was tested using Anderson-Darling statistics at $p \leq 0.05$. The data was normally distributed. In order to fully understand the nature of the variability, a semivariogram analysis was conducted for each soil property at each slope position. SA semivariogram analysis was conducted using GS+ (Gamma Design Software, Plainwell, Michigan) ver. 9. In general, a semivariogram is defined by the following equation (Ayoubi et al., 2007):

$$
\Upsilon(h)=\frac{1}{2 m(h)} \sum_{i=1}^{m(h)}\left[z\left(x_{i}+h\right)-z\left(x_{i}\right)\right]^{2}
$$

where $Y(h)$ is the experimental value of the semivariogram at a distance $h, m(h)$ represents the sample value pairs within the distance $h$, and $z\left(x_{i}+h\right)$ and $z\left(x_{i}\right)$ are sample values at two points separated by distance $h$. The distance tolerance was half the distance between lags. Semivariograms were evaluated by fitting them to theoretical models. Each of these models are defined in terms of nugget variance $\left(C_{0}\right)$, sill (sum of structural variance, $C_{1}$, and nugget variance, $C_{0}$ ), and correlation range $\left(A_{0}\right)$. The nugget effect indicates the variability of the parameter being examined at a scale which is smaller than the sampling interval. As such, nugget effects are present when the semivariogram value increases from a value other than zero. The sill is the value at which no further increase is observed in the semivariogram, while the range is the distance from zero to the point where the semivariogram model flattens out (i.e. reaches about $95 \%$ of the sill value). Each of the four models are briefly defined below (McBratney and Webster, 1986);

Linear isotropic model

$$
\Upsilon(h)=C_{0}+\left[h\left(\frac{C_{1}}{A_{0}}\right)\right]
$$

Spherical isotropic model

$$
\Upsilon(h)= \begin{cases}C_{0}+C_{1}\left[1.5\left(h / A_{0}\right)-0.5\left(h / A_{0}\right)^{3}\right] & h \leq A_{0} \\ C_{0}+C_{1} & h>A_{o}\end{cases}
$$

Exponential isotropic model

$$
\Upsilon(h)=C_{0}+C_{1}\left[1-\exp \left(\frac{-h}{A_{0}}\right)\right]
$$

Gaussian isotropic model

$$
\Upsilon(h)=C_{0}+C_{1}\left[1-\exp \left(\frac{-h^{2}}{A_{0}^{2}}\right)\right]
$$

From the errors (difference between the observed and predicted data) produced from each model, the Root Mean Square Error (RMSE) was calculated according to the following formula:

$$
R M S E=\sqrt{\frac{1}{N} \sum_{i=1}^{n}\{Z(X i)-\hat{Z}(X i)\}^{2}}
$$

where $N$ is the number of samples, $Z(X i)$ is the observed value, and $\hat{Z}(X i)$ is the predicted value. The $\mathrm{F}_{\mathrm{D}}$ value was determined from the slope of the semivariance vs. distance. Also, the degree of spatial dependence $\left(D S D=C_{0} /\left(C_{0}+\right.\right.$ $C_{1}$ ) x 100)) of each variable was determined. A ratio $<25 \%$ represents a strong degree of dependence, $25-75 \%$ shows a moderate degree of dependence, and $>75 \%$ shows a weak degree of dependence (Cambardella et al., 1994). 
Table 2. Pearson correlation coefficient for soil physical and thermal properties at $0 \mathrm{kPa}$ soil water matric potential

\begin{tabular}{|c|c|c|c|c|c|c|}
\hline & $\lambda$ & $\mathrm{C}$ & $\mathrm{D}$ & $\theta$ & SOC & $\rho b$ \\
\hline$\lambda$ & 1.0000 & & & & & \\
\hline $\mathrm{C}$ & $\begin{array}{c}-0.69 \\
(<0.0001)\end{array}$ & 1.0000 & & & & \\
\hline D & $\begin{array}{c}0.94 \\
(<0.0001)\end{array}$ & $\begin{array}{c}-0.89 \\
(<0.0001)\end{array}$ & 1.0000 & & & \\
\hline$\theta$ & $\begin{array}{c}-0.43 \\
(0.0033)\end{array}$ & $\begin{array}{c}0.54 \\
(0.0001)\end{array}$ & $\begin{array}{c}-0.51 \\
(0.0003)\end{array}$ & 1.0000 & & \\
\hline SOC & $\begin{array}{c}0.65 \\
(<0.0001)\end{array}$ & $\begin{array}{c}0.78 \\
(<0.0001)\end{array}$ & $\begin{array}{c}-0.75 \\
(<0.0001)\end{array}$ & $\begin{array}{c}0.63 \\
(<0.0001)\end{array}$ & 1.0000 & \\
\hline$\rho b$ & $\begin{array}{c}0.58 \\
(<0.0001)\end{array}$ & $\begin{array}{c}-0.76 \\
(<0.0001)\end{array}$ & $\begin{array}{c}0.72 \\
(<0.0001)\end{array}$ & $\begin{array}{c}-0.62 \\
(<0.0001)\end{array}$ & $\begin{array}{c}-0.62 \\
(<0.0001)\end{array}$ & 1.0000 \\
\hline
\end{tabular}

$\lambda$ - thermal conductivity, $\mathrm{C}$ - volumetric heat capacity, $\mathrm{D}-$ thermal diffusivity, $\theta$ - volumetric water content, SOC - soil organic carbon, $\rho b$ : soil bulk density.

\section{RESULTS}

The descriptive statistics of soil physical and thermal properties are shown in Table 2. The results showed that SOC was $71 \%$ higher at the toeslope compared with the backslope, which had the lowest SOC. Soil $\rho$ b was 5 and $14 \%$ higher on the backslope compared with the summit and toeslope, respectively. At $0 \mathrm{kPa}$, soil water matric potential
(SWMP), $\lambda$ values at the backslope was $4,6,6$, and $25 \%$ higher compared with the values at the summit, shoulderslope, footslope and toeslope, respectively. Thermal conductivity values were reduced with a decrease in SWMP from 0 to $-33 \mathrm{kPa}$ at the summit, shoulderslope and backslope. At $0 \mathrm{kPa}$ SWMP, C values at the toeslope were 5, 15,16 , and $4 \%$ higher compared with values at the summit, shoulder, back, and foot slopes, respectively. In general, C values decreased with a decrease in SWMP from 0 to -33 $\mathrm{kPa}$. Thermal diffusivity values followed a similar trend to $\lambda$ at 0 and $-33 \mathrm{kPa}$ SWMP. At $0 \mathrm{kPa}$ SWMP, $\theta$ at the toeslope was $16,19,42$ and $13 \%$ higher compared with values at the summit, shoulderslope, backslope and footslope, respectively. At each slope position, $\theta$ values were significantly lower at $-33 \mathrm{kPa}$ SWMP compared with $0 \mathrm{kPa}$ SWMP.

Table 3 shows Pearson's correlations of soil thermal and physical properties at $0 \mathrm{kPa}$ SWMP. The results showed a significant $(p \leq 0.05)$ correlation between the measured soil properties. Soil $\lambda$ was positively correlated with $\rho b(r=0.58, p<0.0001)$ and $\theta(r=0.65, p=0.0033)$ and negatively correlated with SOC. The volumetric heat capacity was positively correlated with $\theta(\mathrm{r}=0.54, \mathrm{p}=$ $0.0001)$ and SOC $(r=0.78, p \leq 0.0001)$ and negatively

Table 3. Descriptive statistics of soil physical and thermal properties at $0 \mathrm{kPa}$ and $-33 \mathrm{kPa}$ soil water matric potentials

\begin{tabular}{|c|c|c|c|c|c|c|c|c|c|c|}
\hline \multirow[b]{2}{*}{ Slope position } & \multirow[b]{2}{*}{$\mathrm{SOC}$} & \multirow[b]{2}{*}{$\rho b$} & \multicolumn{4}{|c|}{$0 \mathrm{kPa}$} & \multicolumn{4}{|c|}{$-33 \mathrm{kPa}$} \\
\hline & & & $\lambda$ & $\mathrm{C}$ & $\mathrm{D}$ & $\theta$ & $\lambda$ & $\mathrm{C}$ & $\mathrm{D}$ & $\theta$ \\
\hline & $\mathrm{g} \mathrm{kg}^{-1}$ & $\mathrm{~g} \mathrm{~cm}^{-3}$ & $\mathrm{~W} \mathrm{m^{-1 }} \mathrm{k}^{-1}$ & $\mathrm{MJ} \mathrm{m}^{-3} \mathrm{~K}^{-1}$ & $\mathrm{~mm}^{2} \mathrm{~s}^{-1}$ & $\mathrm{~cm}^{3} \mathrm{~cm}^{-3}$ & $\mathrm{~W} \mathrm{m^{-1 }} \mathrm{k}^{-1}$ & $\mathrm{MJ} \mathrm{m}^{-3} \mathrm{~K}^{-1}$ & $\mathrm{~mm}^{2} \mathrm{~s}^{-1}$ & $\mathrm{~cm}^{3} \mathrm{~cm}^{-3}$ \\
\hline \multicolumn{11}{|l|}{ Summit } \\
\hline Mean & 18.73 & 1.24 & 1.38 & 2.95 & 0.47 & 0.38 & 1.26 & 2.77 & 0.46 & 0.26 \\
\hline Median & 18.02 & 1.25 & 1.31 & 2.92 & 0.45 & 0.37 & 1.31 & 2.78 & 0.45 & 0.21 \\
\hline Std. Dev & 5.80 & 0.09 & 0.14 & 0.13 & 0.06 & 0.10 & 0.18 & 0.29 & 0.07 & 0.24 \\
\hline $\mathrm{CV}$ & 0.31 & 0.07 & 0.10 & 0.04 & 0.14 & 0.27 & 0.14 & 0.11 & 0.14 & 0.93 \\
\hline \multicolumn{11}{|l|}{ Shoulderslope } \\
\hline Mean & 15.89 & 1.27 & 1.35 & 2.70 & 0.50 & 0.37 & 1.25 & 2.72 & 0.47 & 0.13 \\
\hline Median & 14.83 & 1.29 & 1.30 & 2.66 & 0.47 & 0.33 & 1.22 & 2.72 & 0.44 & 0.13 \\
\hline Std. Dev & 4.10 & 0.09 & 0.14 & 0.16 & 0.08 & 0.11 & 0.12 & 0.32 & 0.06 & 0.07 \\
\hline $\mathrm{CV}$ & 0.26 & 0.07 & 0.11 & 0.06 & 0.16 & 0.29 & 0.10 & 0.12 & 0.13 & 0.56 \\
\hline \multicolumn{11}{|l|}{ Backslope } \\
\hline Mean & 13.76 & 1.30 & 1.43 & 2.62 & 0.55 & 0.31 & 1.37 & 2.68 & 0.53 & 0.15 \\
\hline Median & 12.79 & 1.33 & 1.42 & 2.62 & 0.56 & 0.33 & 1.34 & 2.78 & 0.47 & 0.13 \\
\hline Std. Dev & 4.57 & 0.08 & 0.11 & 0.13 & 0.06 & 0.10 & 0.26 & 0.36 & 0.15 & 0.07 \\
\hline $\mathrm{CV}$ & 0.33 & 0.06 & 0.07 & 0.05 & 0.11 & 0.32 & 0.19 & 0.14 & 0.28 & 0.51 \\
\hline \multicolumn{11}{|l|}{ Footslope } \\
\hline Mean & 19.90 & 1.23 & 1.35 & 2.97 & 0.46 & 0.39 & 1.43 & 2.80 & 0.52 & 0.17 \\
\hline Median & 18.02 & 1.23 & 1.38 & 2.98 & 0.46 & 0.40 & 1.43 & 2.72 & 0.57 & 0.16 \\
\hline Std. Dev & 6.35 & 0.10 & 0.17 & 0.18 & 0.08 & 0.05 & 0.24 & 0.25 & 0.12 & 0.04 \\
\hline $\mathrm{CV}$ & 0.32 & 0.08 & 0.13 & 0.06 & 0.18 & 0.14 & 0.17 & 0.09 & 0.23 & 0.26 \\
\hline \multicolumn{11}{|l|}{ Toeslope } \\
\hline Mean & 23.58 & 1.14 & 1.25 & 3.10 & 0.41 & 0.44 & 1.30 & 2.82 & 0.47 & 0.23 \\
\hline Median & 21.51 & 1.13 & 1.21 & 3.13 & 0.40 & 0.50 & 1.33 & 2.83 & 0.47 & 0.24 \\
\hline Std. Dev & 7.09 & 0.08 & 0.14 & 0.17 & 0.07 & 0.14 & 0.17 & 0.24 & 0.09 & 0.10 \\
\hline $\mathrm{CV}$ & 0.30 & 0.07 & 0.12 & 0.05 & 0.16 & 0.32 & 0.13 & 0.09 & 0.18 & 0.46 \\
\hline
\end{tabular}

SOC - soil organic carbon, $\rho b$ - soil bulk density, $\lambda$ - thermal conductivity, $\mathrm{C}$ - volumetric heat capacity, $\mathrm{D}$ - thermal diffusivity; $\theta$ - volumetric water content, Std. Dev - standard deviation, CV - coefficient of variation. 
a)
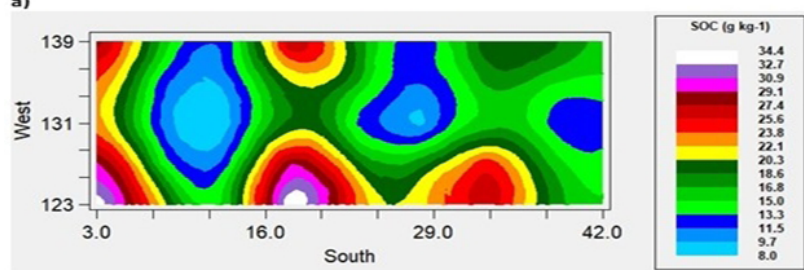

b)

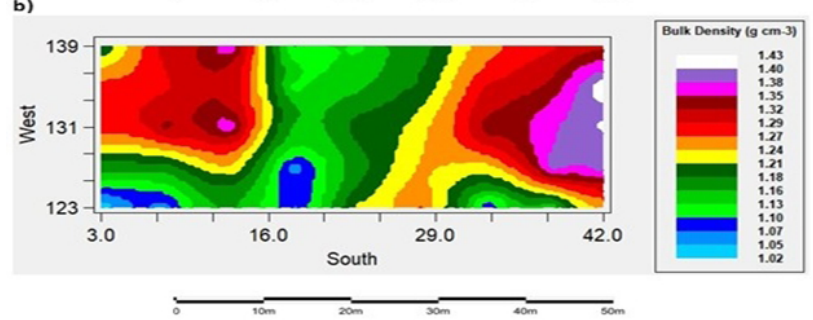

Fig. 2. Spatial variability and semivariogram of a) soil organic matter (SOC), and b) bulk density across all five slope positions. Please note that the $\mathrm{x}$ and $\mathrm{y}$ axis are the georeferenced $\mathrm{x}$ and $\mathrm{y}$ coordinates for the study site.

correlated with $\rho b$. Thermal diffusivity was positively correlated with $\rho b(r=0.72, p<0.0001)$ and negatively correlated with $\theta$ and SOC.

Soil physical and thermal properties were spatially distributed across five slope positions (Figs 2-4, Table 4). Four isotropic models provided the best fit for the data in the current study: linear, spherical, exponential, and Gaussian. The root mean square error for the isotropic models used in the current study showed a good prediction. The semivariogram model fit was determined from the coefficient of determination $\left(\mathrm{R}^{2}\right)$ values. Soil organic carbon showed a good spatial distribution across the hillslope with the highest values located around the southern portion of the map (which corresponds to the toeslope position (Fig. 2a). As expected, soil bulk density also showed a good spatial distribution across the landscape with the lowest bulk density values being obtained around the toeslope position (Fig. 2b). Furthermore, the results show that $\mathrm{C}$ and $\mathrm{D}$ were more spatially distributed compared with $\lambda$ (Figs 3 and $4 a)$. The best model fit for thermal properties at the summit, shoulderslope, and backslope was a linear isotropic model $\left(\mathrm{R}^{2}>0.86\right)$. At the footslope, the Gaussian isotropic model $\left(\mathrm{R}^{2}=0.89\right)$ provided the best fit, while the spherical isotropic model provided the best fit $\left(\mathrm{R}^{2}=0.95\right)$ at the toeslope position. The best model fit for soil thermal properties across all slope positions at $0 \mathrm{kPa}$ SWMP was the spherical isotropic model $\left(\mathrm{R}^{2}=0.95\right)$, while at $-33 \mathrm{kPa}$ SWMP the best model fit across all slope positions was the linear isotropic $\left(\mathrm{R}^{2}=0.95\right)$ model. At $0 \mathrm{kPa}$, soil thermal properties mainly responded to the Gaussian isotropic model at all slope positions. At $-33 \mathrm{kPa}$, the linear isotropic model was the most common at all slope positions. At $0 \mathrm{kPa}$, the spherical isotropic model provided the best fit for $\lambda$ $\left(\mathrm{R}^{2}=0.95\right.$, toeslope), while at $-33 \mathrm{kPa}$, the linear isotropic model provided the best fit for $\lambda\left(\mathrm{R}^{2}=0.95\right.$, toeslope $)$. At
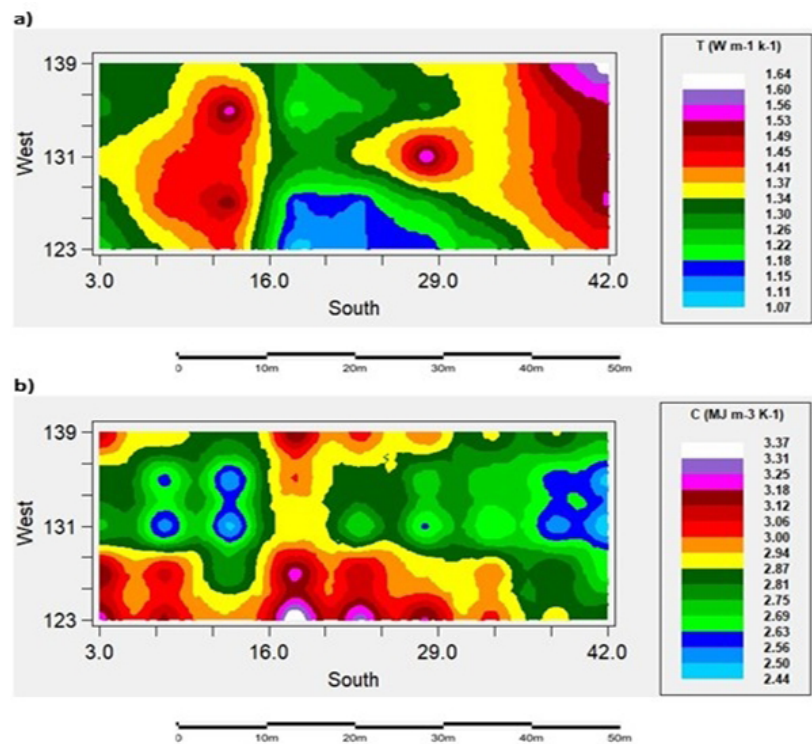

Fig. 3. Spatial variability and semivariogram of a) thermal conductivity (T), and b) volumetric heat capacity (C) across all five slope positions. Please note that the $\mathrm{x}$ and $\mathrm{y}$ axis are the georeferenced $\mathrm{x}$ and $\mathrm{y}$ coordinates for the study site.

a)
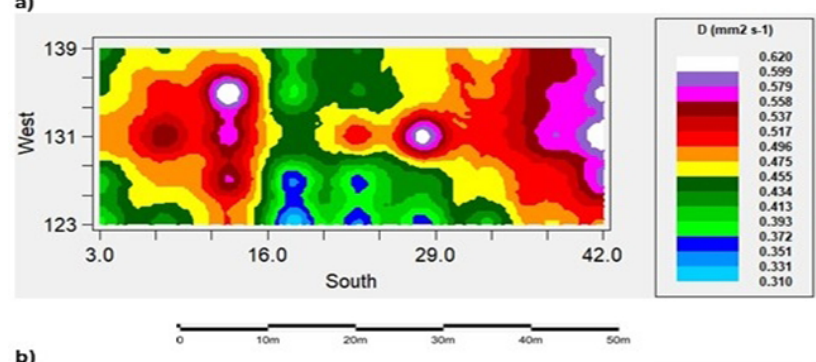

b)

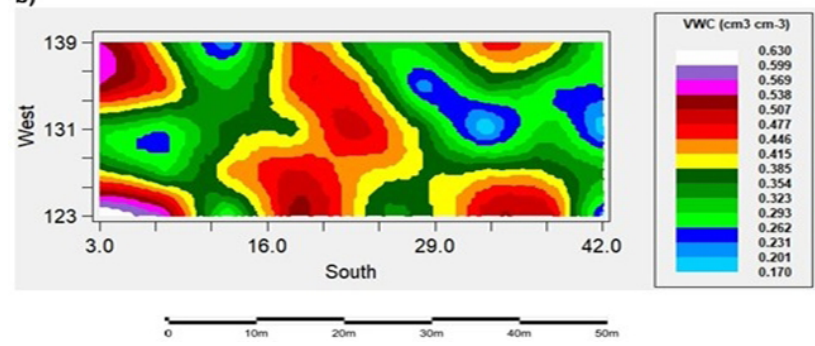

Fig. 4. Spatial variability and model representation of a) thermal diffusivity (D), and b) volumetric water content (VWC) at saturation, across all five slope positions. Please note that the $\mathrm{x}$ and $\mathrm{y}$ axis are the georeferenced $\mathrm{x}$ and $\mathrm{y}$ coordinates for the study site.

$0 \mathrm{kPa}$, the Gaussian isotropic model provided the best fit for $\mathrm{C}\left(\mathrm{R}^{2}=0.94\right.$, toeslope $)$ while at $-33 \mathrm{kPa}$, the linear isotropic model provided the best fit for $\mathrm{C}\left(\mathrm{R}^{2}=0.91\right.$, shoulderslope $)$. At $0 \mathrm{kPa}$, the Gaussian isotropic model provided the best fit for $\mathrm{D}\left(\mathrm{R}^{2}=0.94\right.$ toeslope), while at $-33 \mathrm{kPa}$, the linear model provided the best fit for $\mathrm{D}\left(\mathrm{R}^{2}=0.78\right)$. At 0 and $-33 \mathrm{kPa}$ SWMP, the Gaussian isotropic model provided the best fit for $\theta\left(R^{2}=0.77\right.$ and 0.79 , respectively, back slope $)$. At all slope positions, the linear isotropic model provided the best fit for SOC $\left(\mathrm{R}^{2}=0.68\right.$, backslope $)$, while the linear isotropic model provided the best fit for $\rho b\left(R^{2}=0.98\right.$, backslope $)$. 
Table 4. Spatial and fractal characteristics of physical and thermal properties at $0 \mathrm{kPa}$ and $-33 \mathrm{kPa}$ soil water matric potentials

\begin{tabular}{|c|c|c|c|c|c|c|c|c|c|c|}
\hline \multirow[b]{2}{*}{ Slope position } & \multirow[b]{2}{*}{$\mathrm{SOC}$} & \multirow[b]{2}{*}{$\rho b$} & \multicolumn{4}{|c|}{$0 \mathrm{kPa}$} & \multicolumn{4}{|c|}{$-33 \mathrm{kPa}$} \\
\hline & & & $\lambda$ & $\mathrm{C}$ & $\mathrm{D}$ & $\theta$ & $\lambda$ & $\mathrm{C}$ & $\mathrm{D}$ & $\theta$ \\
\hline \multicolumn{11}{|l|}{ Summit } \\
\hline Model & Linear & Spherical & Gaussian & Gaussian & Gaussian & Linear & Linear & Linear & Linear & Linear \\
\hline Nugget & 27.608 & 0.002 & 0.000 & 0.011 & 0.000 & 0.008 & 0.029 & 0.080 & 0.005 & 0.059 \\
\hline Sill & 27.608 & 0.025 & 0.200 & 0.122 & 0.067 & 0.008 & 0.029 & 0.080 & 0.005 & 0.059 \\
\hline Nugget/Sill & 0.000 & 0.913 & 1.000 & 0.910 & 0.999 & 0.000 & 0.000 & 0.000 & 0.000 & 0.000 \\
\hline$A_{0}(\mathrm{~m})$ & 19.000 & 36.460 & 55.530 & 71.014 & 71.014 & 19.000 & 19.000 & 19.00 & 19.000 & 19.000 \\
\hline $\mathrm{R}^{2}$ & 0.65 & 0.89 & 0.76 & 0.76 & 0.77 & 0.632 & 0.90 & 0.46 & 0.57 & 0.05 \\
\hline RMSE & 15.780 & 0.001 & 0.009 & 0.003 & 0.002 & 0.004 & 0.014 & 0.038 & 0.002 & 0.026 \\
\hline$D S D(\%)$ & 27.608 & 0.002 & 0.001 & 0.012 & 0.001 & 0.008 & 0.029 & 0.080 & 0.005 & 0.059 \\
\hline FD & 0.857 & 1.618 & 1.232 & 1.714 & 1.271 & 1.299 & 0.862 & 0.484 & 1.062 & 1.542 \\
\hline \multicolumn{11}{|l|}{ Shoulderslope } \\
\hline Model & Linear & Gaussian & Gaussian & Gaussian & Gaussian & Exponential & Spherical & Linear & Linear & Linear \\
\hline Nugget & 14.306 & 0.000 & 0.021 & 0.018 & 0.005 & 0.006 & 0.000 & 0.087 & 0.004 & 0.006 \\
\hline Sill & 14.306 & 0.179 & 0.101 & 0.234 & 0.053 & 0.029 & 0.017 & 0.087 & 0.004 & 0.006 \\
\hline Nugget/Sill & 0.000 & 0.999 & 0.798 & 0.922 & 0.897 & 0.801 & 0.999 & 0.000 & 0.000 & 0.000 \\
\hline$A_{0}(\mathrm{~m})$ & 19.00 & 71.014 & 71.000 & 71.014 & 71.014 & 123.000 & 4.870 & 19.000 & 19.000 & 19.000 \\
\hline $\mathrm{R}^{2}$ & 0.61 & 0.91 & 0.69 & 0.68 & 0.73 & 0.28 & 0.24 & 0.91 & 0.25 & 0.55 \\
\hline$R M S E$ & 6.650 & 0.003 & 0.002 & 0.007 & 0.001 & 0.002 & 0.003 & 0.040 & 0.004 & 0.002 \\
\hline$D S D(\%)$ & 14.306 & 0.000 & 0.026 & 0.020 & 0.006 & 0.007 & 0.000 & 0.087 & 0.004 & 0.006 \\
\hline FD & 1.374 & 1.237 & 1.836 & 1.690 & 1.727 & 1.873 & 1.932 & 0.120 & 1.936 & 1.691 \\
\hline \multicolumn{11}{|l|}{ Backslope } \\
\hline Model & Linear & Gaussian & Linear & Exponential & Spherical & Gaussian & Exponential & Linear & Linear & Gaussian \\
\hline Nugget & 14.902 & 0.003 & 0.012 & 0.014 & 0.000 & 0.000 & 0.057 & 0.104 & 0.021 & 0.000 \\
\hline Sill & 14.902 & 0.070 & 0.012 & 0.044 & 0.004 & 0.200 & 0.155 & 0.104 & 0.021 & 0.144 \\
\hline Nugget/Sill & 0.000 & 0.964 & 0.000 & 0.683 & 0.934 & 1.000 & 0.635 & 0.000 & 0.000 & 0.999 \\
\hline$A_{0}(\mathrm{~m})$ & 19.000 & 58.128 & 19.000 & 104.850 & 6.420 & 63.549 & 123.000 & 19.000 & 19.000 & 71.014 \\
\hline $\mathrm{R}^{2}$ & 0.68 & 0.98 & 0.46 & 0.31 & 0.05 & 0.77 & 0.20 & 0.86 & 0.75 & 0.79 \\
\hline RMSE & 8.819 & 0.007 & 0.003 & 0.003 & 0.001 & 0.006 & 0.013 & 0.042 & 0.003 & 0.004 \\
\hline$D S D(\%)$ & 14.902 & 0.003 & 0.012 & 0.021 & 0.000 & 0.000 & 0.089 & 0.104 & 0.021 & 0.000 \\
\hline FD & 0.743 & 1.433 & 1.743 & 1.869 & 1.920 & 1.445 & 1.913 & 0.808 & 1.788 & 1.369 \\
\hline \multicolumn{11}{|l|}{ Footslope } \\
\hline Model & Linear & Gaussian & Gaussian & Gaussian & Gaussian & Spherical & Linear & Linear & Linear & Linear \\
\hline Nugget & 33.921 & 0.002 & 0.012 & 0.013 & 0.002 & 0.000 & 0.066 & 0.055 & 0.015 & 0.002 \\
\hline Sill & 33.921 & 0.102 & 0.459 & 0.236 & 0.108 & 0.004 & 0.066 & 0.055 & 0.015 & 0.002 \\
\hline Nugget/Sill & 0.000 & 0.981 & 0.974 & 0.944 & 0.980 & 0.929 & 0.000 & 0.000 & 0.000 & 0.00 \\
\hline$A_{0}(\mathrm{~m})$ & 19.000 & 71.014 & 70.010 & 58.006 & 71.014 & 8.150 & 19.000 & 19.000 & 19.000 & 19.000 \\
\hline $\mathrm{R}^{2}$ & 0.62 & 0.84 & 0.89 & 0.52 & 0.76 & 0.36 & 0.03 & 0.73 & 0.12 & 0.49 \\
\hline$R M S E$ & 15.755 & 0.002 & 0.007 & 0.014 & 0.003 & 0.008 & 0.016 & 0.020 & 0.003 & 0.005 \\
\hline$D S D(\%)$ & 33.921 & 0.002 & 0.012 & 0.014 & 0.002 & 0.000 & 0.066 & 0.055 & 0.015 & 0.002 \\
\hline FD & 1.372 & 1.503 & 1.459 & 1.728 & 1.513 & 1.966 & 1.853 & 1.484 & 1.826 & 1.694 \\
\hline \multicolumn{11}{|l|}{ Toeslope } \\
\hline Model & Linear & Linear & Spherical & Gaussian & Gaussian & Linear & Linear & Linear & Linear & Linear \\
\hline Nugget & 45.296 & 0.005 & 0.009 & 0.010 & 0.003 & 0.018 & 0.023 & 0.057 & 0.006 & 0.007 \\
\hline Sill & 45.296 & 0.005 & 0.062 & 0.219 & 0.037 & 0.018 & 0.023 & 0.057 & 0.006 & 0.007 \\
\hline Nugget/Sill & 0.000 & 0.000 & 0.851 & 0.954 & 0.916 & 0.000 & 0.000 & 0.000 & 0.000 & 0.000 \\
\hline$A_{0}(\mathrm{~m})$ & 19.00 & 19.000 & 41.000 & 53.538 & 65.420 & 19.000 & 19.000 & 19.000 & 19.000 & 19.000 \\
\hline $\mathrm{R}^{2}$ & 0.36 & 0.58 & 0.95 & 0.90 & 0.94 & 0.10 & 0.94 & 0.35 & 0.78 & 0.49 \\
\hline$R M S E$ & 13.912 & 0.002 & 0.001 & 0.005 & 0.005 & 0.004 & 0.008 & 0.022 & 0.003 & 0.003 \\
\hline$D S D(\%)$ & 45.296 & 0.005 & 0.011 & 0.010 & 0.003 & 0.018 & 0.023 & 0.057 & 0.006 & 0.007 \\
\hline FD & 1.699 & 0.999 & 1.687 & 1.495 & 1.621 & 1.853 & 1.420 & 1.611 & 0.483 & 1.190 \\
\hline
\end{tabular}

SOC - soil organic carbon, $\rho \mathrm{b}$ - soil bulk density, $\lambda$ - thermal conductivity, $\mathrm{C}$ - volumetric heat capacity, $\mathrm{D}$ - thermal diffusivity; $\theta$ - volumetric water content, $A_{0}$ - range of spatial variability, $D S D$ - degree of spatial dependence, FD - fractal dimension. Other explanations as in Table 2. 
The range of spatial variability $\left(A_{0}\right)$ of the semivariogram is the interval between the correlated measurements and may be utilized as an effective evaluation criterion of the sampling designs and mapping soil properties. At $0 \mathrm{kPa}$, the $A_{0}$ of the soil thermal properties was between 6.4 and $104.9 \mathrm{~m}$ at all slope positions. At $-33 \mathrm{kPa}$ SWMP, the $A_{0}$ of the soil thermal properties was between 4.9 and $123 \mathrm{~m}$ at all slope positions. At 0 and $-33 \mathrm{kPa} \mathrm{SWMP}$, the $A_{0}$ for $\theta$ at all slope positions was between 8.2 and $123 \mathrm{~m}$ and between 19 and $71 \mathrm{~m}$, respectively. The $A_{0}$ for SOC was $19 \mathrm{~m}$, while that of $\rho b$ was between 19 and $71 \mathrm{~m}$ at all slope positions.

The DSD provides information on the relationship between the spatial proximity among the observed units and the numeric similarity among their values (Lee, 2017). The results of the current study indicated a strong spatial dependence $(D S D \leq 25 \%)$ for thermal properties, $\rho b$, and $\theta$ across all slope positions and matric potentials. Except for the summit, foot and toe slopes, SOC exhibited a strong spatial dependence across the investigated landscape positions (Table 4). The strong spatial dependence may be controlled by inherent variations in soil characteristics such as texture and mineralogy, while extrinsic factors such as soil management may control the variability of the weak spatially dependent parameters.

Table 4 shows the $F_{D}$ of soil properties across several landscape positions and matric potentials. The $\mathrm{F}_{\mathrm{D}}$ of SOC ranged between 0.743-1.699, while that of $\rho b$ ranged from 0.999-1.618. At $0 \mathrm{kPa}$, the $\mathrm{F}_{\mathrm{D}}$ of $\theta$ ranged from 1.299-1.966, while at $-33 \mathrm{kPa}$ SWMP, it ranged from 1.190-1.694. At saturation on the summit, the dimensions of the $\lambda$ and $D$ fractals were easier to describe with a length rather than an area, while that of $\mathrm{C}$ was easier to describe with an area. At all other slope positions (at $0 \mathrm{kPa}$ SWMP), the $\mathrm{F}_{\mathrm{D}}$ of the soil thermal properties resembled more of an area than a length. On the summit at $-33 \mathrm{kPa}$ SWMP, the $\mathrm{F}_{\mathrm{D}}$ of the soil thermal properties generally approach a length. On the shoulder and back slopes ( $-33 \mathrm{kPa}$ SWMP) the dimensions of the $\lambda$ and $\mathrm{D}$ fractals approach an area, while that of $\mathrm{C}$ approaches a length. At the foot slope ( $-33 \mathrm{kPa}$ SWMP), the $F_{D}$ of the soil thermal properties were easier to describe with an area. At the toe slope ( $-33 \mathrm{kPa}$ SWMP), the $\mathrm{F}_{\mathrm{D}}$ of $\lambda$ and $\mathrm{C}$ were similar to an area while that of D was similar to a length. In general, at saturation, the $\mathrm{F}_{\mathrm{D}}$ for soil thermal properties at all slope positions ranged from $1.232-1.920$, while at $-33 \mathrm{kPa}$ SWMP, it ranged from 0.120-1.936.

\section{DISCUSSIONS}

The higher SOC value at the toeslope was attributed to a greater deposition of residues by gravity, and by the action of water and/or wind at the back slope (Burke et al., 1999; Longbottom et al., 2014) and less microbial activity due to the anaerobic conditions prevalent at the toe slope (Garcia-Pausas et al., 2007). The lowest SOC values at the backslope were probably due to slope steepness, the higher erodibility at these positions, and a greater degree of microbial breakdown from a more favourable soil condition. Conversely, Garcia-Pausas et al. (2007) reported the lowest SOC value at the summit due to the temperature limitation of net primary productivity. One reason for this contrast could be the slope aspect. In the current study, the southfacing slopes are perpendicular to the sunlight, while the slopes in the study by Garcia-Pausas et al. (2007) were not. Soil $\rho b$ was consistent with the SOC results which could be due to the susceptibility of the backslope to runoff, less moisture (which accelerates the breakdown of SOC), and less biopores. Due to the deposition of SOC which is usually noticed at the foot and toe slopes, $\rho b$ was lowest at these slope positions. Oztas et al. (2003) reported similar findings. In contrast, Khan et al. (2013) reported lower $\rho$ b values on the summit compared to other landscape positions due to soil textural differences. The summit had a significantly higher sand content and a lower clay content compared to other landscape positions (Khan et al., 2013). This contrast could also have been the result of differences in SOC content. The current study had 175, 50, and 39\% higher SOC values at the summit, back, and foot slopes respectively, as compared to the study conducted by Khan et al. (2013).

The lower $\lambda$ values at $0 \mathrm{kPa}$ SWMP were attributed to higher $\rho b$ values at the backslope position. Since the $\lambda$ value of soil minerals is higher than the $\lambda$ value of other soil constituents (Bristow, 2002), as $\rho b$ increases, the contact between soil particles also increases, thus increasing the $\lambda$ value. As such, landscape positions with higher $\rho b$ values had higher $\lambda$ values (Table 2). Additionally, the $\lambda$ value of SOC $\left(0.25 \mathrm{~W} \mathrm{~m}^{-1} \mathrm{~K}^{-1}\right)$ is lower than that of clays $\left(2.9 \mathrm{~W} \mathrm{~m}^{-1} \mathrm{~K}^{-1}\right)$ (Bristow, 2002) and SOC can lower $\rho b$, therefore higher SOC can reduce $\lambda$. Water drainage between 0 and $-33 \mathrm{kPa}$ SWMP was probably responsible for the difference in $\lambda$ values between these pressures at the summit, shoulderslope and backslope. As the water drains out of the soil pores, it is quickly replaced by air. Since the $\lambda$ of air $\left(0.025 \mathrm{~W} \mathrm{~m}^{-1} \mathrm{~K}^{-1}\right)$ is lower than that of water $\left(0.57 \mathrm{~W} \mathrm{~m}^{-1} \mathrm{~K}^{-1}\right)$, a decrease in water content reduced $\lambda$ from 0 to $-33 \mathrm{kPa}$ SWMP.

The highest $\mathrm{C}$ values at the toeslope were attributed to water content and SOC. The $\mathrm{C}$ value of water is significantly higher than that of other soil constituents (Bristow, 2002), thus, a higher water content leads to higher $C$ values. Rapid water drainage between 0 and $-33 \mathrm{kPa}$ SWMP also resulted in a significant reduction in $\mathrm{C}$ values between these pressures. Furthermore, since SOC acts in a similar way to colloids with a higher surface area, they tend to increase water availability, which may be responsible for the higher $\mathrm{C}$ values at landscape positions with higher SOC values. The thermal diffusivity was similar to $\lambda$ at all slope positions and SWMP because D is a function of the ratio of $\lambda$ to $C$. Therefore, factors that increase $\lambda$ and reduce $\mathrm{C}$ will increase D values (Haruna et al., 2017). Volumetric water content was higher at the toeslope, this is probably due to the higher SOC values and lower $\rho b$ values at this slope position. In 
contrast, Mohanty and Mousil (2000) reported no significant differences in $\theta$ across various slope positions as a result of similarities between SOC across these slope positions.

The significant correlation between $\rho b$ and $\lambda$ shows that the soil can warm quickly and to a deeper depth at the shoulder and back slopes. As $\rho_{b}$ increases, pore spaces are reduced and thedegree of contact between soil minerals increases, thus conducting more heat. Additionally, as SOC and $\theta$ increased across different slope positions, $C_{V}$ also increased. This increase was higher at the foot and toe slopes compared to other slope positions (Table 2). Similarly, Abu-Hamdeh and Reeder (2000) and Haruna (2019) reported an inverse relationship between SOC and $\lambda$ under laboratory conditions.

Correlation results show that foot and toe slope positions may be more suitable for $\theta$ conservation and reducing soil thermal conductance. Nonetheless, thermal conductance is also dependent on the amount of solar radiation reaching the soil surface. Due to the slope aspect, the shoulder and back slope will receive more solar radiation, increasing Өevaporation and resulting in the depletion of SOC. This will further increase thermal conductance on the shoulder and back slope positions. Results from the current study suggests that, in a more variable climate, the foot and toe slope positions may be able to better buffer against extreme soil heat change compared with other slope positions. Further studies onconcerning the interaction effects between slope position and various land management practices on soil thermal properties will provide more useful information about crop productivity in a rapidly changing global climate.

Spatial variability maps (Fig. 2) further illustrate the inverse relationship between SOC and bulk density described above. The probable reason for the improved spatial distribution of $\mathrm{C}$ and $\mathrm{D}$ compared with $\lambda$ could be due to the influence of SOC and $\theta$ on C. Since D is the ratio of $\lambda$ and $C$, changes in $C$ will certainly influence $D$. This suggests that, along a hillslope, $\mathrm{C}$ and $\mathrm{D}$ are more difficult to predict spatially as compared to $\lambda$.

The spherical, exponential, and Gaussian isotropic models indicate an inverse relationship between spatial autocorrelation and distance (Burrough, 1986; McBratney and Webster, 1986). Since the spherical, exponential and Gaussian isotropic models provided the best model fit for soil thermal properties at saturation (Table 4), results from the current study suggests that, among other factors, the similarity between soil thermal properties is highly dependent on the volumetric water content at all slope positions. In order to avoidexcessive similarities between the soil thermal propertiesproperty results and capture sufficient variability for future studies, the distance between soil samples should be further apart under wet soil conditions (between 0 and $-33 \mathrm{kPa}$ SWMP). The drier the soil, the closer the distance between soil samples (see range of spatial variability in Table 4). The reason for this could be that the $\lambda$ and $C$ values for water are greater than those ofproduced by air.
In theory, the semivariogram value is null at the null separation distance (no lag). However, the semivariogram often exhibits a nugget effect at a very small lag, which is a value greater than zero. This nugget effect may be attributed to spatial sources of variation at smaller distances than the sampling interval, measurement errors, or both. In order to eliminate measurement errors, replicate samples were collected. Thus, the nugget effect in the current study may be attributed to spatial sources of variation at distances smaller than the sampling interval. At $0 \mathrm{kPa}$ SWMP, the nugget effect of soil thermal properties was highest for $\mathrm{C}$ and $\lambda$ at the shoulderslope. This suggests that at $0 \mathrm{kPa}$ SWMP, C and $\lambda$ were more spatially variable over small distances at the shoulderslope compared with other slope positions. At $-33 \mathrm{kPa}$ SWMP, C showed the highest degree of spatial variability within small distances at all slope positions (apart from the footslope position) compared to other measured thermal properties. This microvariability may be attributed to the sensitivity and dependence of $\mathrm{C}$ to dynamic soil properties ( $\theta$ and SOC). Soil organic carbon had the highestdegree of variability in spatial dependence of all properties measured at all slope positions.

In general, the $A_{0}$ of soil thermal properties was lower at the toe slope compared with the other slope positions, thereby suggesting that soil thermal properties are more homogeneous at this position compared with other slope positions. For the purposes of conducting a statistical analysis, an understanding of the $A_{0}$ value for various soil thermal properties could allow for the construction of independently accurate datasets for similar slope positions in future soil sampling designs. This may be used as a tool in the designation of areas for resampling, and to design future field experiments that avoid spatial dependence. Kerry and Oliver (2004) suggested that the sample interval should be less than half the $A_{0}$ value. As such, for future studies concerning the characterization of the spatial dependency of soil thermal properties in a similar landscape, it is recommended that soil thermal properties should be sampled at distances smaller than half the $A_{0}$ found in the current study (Table 4).

The strong $D S D$ of soil thermal properties in the current study suggests, regardless of slope position that their spatial autocorrelation depends more on intrinsic soil properties rather than on extrinsic properties. As such, the sampling design for future studies concerning soil thermal properties on similar landscape positions should be based on textural and mineralogical characteristics rather than on soil management. For SOC, intrinsic properties only play a role at the steepest parts of the landscape. Therefore, in order to avoid redundancy and to capture variability, SOC sampling decisions concerning the summit, foot, and toe slopes should be based on current land management.

Long- and short-range variation in soil properties have been related to the length and area description, respectively, of their $F_{D}$ (Burrough, 1981). At saturation on the summit, $\lambda$ and $\mathrm{D}$ exhibited long-range variabilities while $\mathrm{C}$ exhib- 
ited a tendency to change over short distances. At other slope positions, the measured soil thermal properties exhibited a likelihood to vary over small distances. At $-33 \mathrm{kPa}$ SWMP, the measured soil thermal properties exhibited a long-range variability at the summit. This was probably due to the significantly lower $\theta$ values at this pressure.

The wider range of $F_{D}$ at $-33 \mathrm{kPa}$ SWMP suggests that as the soil dries, soil thermal properties tend to be less selfsimilar. This isoccurs in concert with results onconcerning the $A_{0}$ values. Results show that, under laboratory conditions, variability in soil matric potentials leads to a greater proportion of short-range variations in soil thermal properties. Furthermore, the results of the current study show that the soil thermal and physical properties at each slope position are influenced by several intrinsic and dynamic soil characteristics. Therefore, management decisions should be tailored uniquely for each slope position rather than for the entire catena. In a more variable climate, with the increasing probability of longer periods of drought, current results suggest that soil thermal properties across these slope positions will become more erratic, which indicates a significant degree of disorder and antipersistence in the spatial structure.

\section{CONCLUSIONS}

1. Statistical analysis semivariogram analysis showed that the Gaussian $\left(\mathrm{R}^{2}=0.89\right)$ and linear $\left(\mathrm{R}^{2}=0.91\right)$ isotropic models provided the best fit for soil thermal properties at 0 and $-33 \mathrm{kPa}$ soil water matric potential, respectively, across the slope positions.

2. The range of autocorrelation was wider at $-33 \mathrm{kPa}$ compared with $0 \mathrm{kPa}$ soil water matric potential for all soil thermal properties, thereby suggesting that soil water content may be an important consideration when planning future sampling schemes to avoid spatial dependence.

3. Significant correlations between soil physical and thermal properties suggest that foot and toe slope positions may provide a better buffer against extreme heat change and are more suitable for crop productivity as compared to other slope positions.

4. The spatial autocorrelation of soil thermal properties depends more on textural characteristics rather than on management practices.

Conflict of interest: The authors declare no conflict of interest.

\section{REFERENCES}

Abu-Hamdeh H.N., and Reeder R.C., 2000. Soil thermal conductivity: effects of density, moisture, salt concentrations and organic matter. Soil Sci. Soc. Am. J., 64, 1285-1290, https://doi.org/10.2136/sssaj2000.6441285x.

Adhikari P., Udawatta R.P., and Anderson S.H., 2014. Soil thermal properties under prairies, conservation buffers, and corn-soybean land use systems. Soil Sci. Soc. Am. J., 78, 1977-1986, https://doi:10.2136/sssaj2014.02.0074
Ayoubi S.H., Zamani S.M., and Khomali F., 2007. Spatial variability of some soil properties for site specific farming in northern Iran. J. Plant Prod., 2, 225-236.

Bogunovic I., Pereira P., and Brevick B.B., 2017. Spatial distribution of soil chemical properties in an organic farm in Croatia. Sci. Total Environ., 584, 535-545, https://doi. org/10.1016/j.scitotenv.2017.01.062.

Bogunovic I., Mesic M., Zgorelec Z., Jurisic A., and Bilandzija D., 2014. Spatial variation of soil nutrients on sandy-loam soil. Soil Till. Res., 144, 174-183. http://dx.doi. org/10.1016/j.still.2014.07.020.

Brady N.C., and Weil R.R., 2008. The nature and properties of soils $\left(14^{\text {th }}\right.$ ed.). Prentice-Hall Inc.: Upper Saddle River, NJ, USA, 60-62.

Bristow K.L., 2002. Thermal conductivity. In: J.H. Dane and G.C. Topp, (eds.). Methods of Soil Analysis. Part 4. SSSA Book Ser. 5. SSSA, Madison, WI, 1209-1226, https://doi. org/10.2136/sssabookser5.4.c50

Burke I.C., Lauenroth W.K., Riggle R., Brannen P., Madigan B., and Beard S., 1999. Spatial variability of soil properties in shortgrass steppe: the relative importance of topography, grazing, microsite, and plant species in controlling spatial patterns. Ecosystems. 2, 422-438, https://doi. org/10.1007/s100219900091.

Burrough P.A., 1981. Fractal dimensions of landscapes and their environmental data. Nature, 294, 240-242, https://doi. org/10.1038/294240a0

Burrough P.A., 1986. Principles of Geographical Information Systems for land resources assessment. New York: Oxford University Press, 102-119.

Cambardella C.A., Moorman T.B., Parkin T.B., Karlen D.L., Novak J.M., Turco R.F., and Konopka A.E., 1994. Fieldscale variability of soil properties in central Iowa soils. Soil Sci. Soc. Am. J., 58, 1501-1511. http://dx.doi.org/10.2136/ sssaj1994.03615995005800050033x.

Cressie N., 1991. Statistics for spatial data. Wiley, New York, 900.

Dahiya R., Ingwersen J., and Streck T., 2007. The effect of mulching and tillage on the water and temperature regimes of a loess soil: Experimental findings and modeling. Soil Till. Res., 96, 52-63, https://doi.org/10.1016/j.still.2007.02.004.

Dane J.H., and Hopmans J.W., 2002. Water retention and storage. In: J.H. Dane and G.C. Topp, editors, Methods of Soil Analysis. Part 4: Physical Methods. SSSA Book. SSSA, Madison, WI, 671-717, https://doi.org/10.2136/sssabookser5.4

Eghball B., Ferguson R.B., Varvel G.E., Hergert G.W., and Gotway C.A., 1997. Fractal characterization of spatial and temporal variability in site-specific and long-term studies. In: Fractal frontiers, ed. M. M. Novak and T. G. Dewey, 339-348. Singapore, Singapore: World Scientific.

Fabijanczyk P., Zawadzki J., and Magiera T., 2017. Magnetometric assessment of soil contamination in problematic area using empirical Bayesian and indicator kriging: A case study in Upper Silesia, Poland. Geoderma, 308, 69-77, https://doi.org/10.1016/j.geoderma.2017.08.029.

Fu W., Tunney H., and Zhang C., 2010. Spatial variation of soil nutrients in a dairy farm and its implications for site-specific fertilizer application. Soil Till. Res., 106, 185-193. http:// dx.doi.org/10.1016/j.still.2009.12.001. 
Gamage D.N.V., Biswas A., and Strachan I.B., 2019. Spatial variability of soil thermal properties and their relationships with physical properties at field scale. Soil Till. Res., 193, 50-58, https://doi.org/10.1016/j.still.2019.05.012

Garcia-Pausas J., Casals P., Camarero L., Huguet C., Sebastia M.T., Thompson R., and Romanya J., 2007. Soil organic carbon storage in mountain grasslands of the Pyrenees: effects of climate and topography. Biogeochemistry, 82, 279-289, https://doi.org/10.1007/s10533-007-9071-9

Gee G.W., and Or D., 2002. Particle-size analysis. In: J.H. Dane and G.C. Topps, editors, Methods of soil analysis. Part 4. SSSA Book Ser. 5. SSSA, Madison, WI, 272-278.

Grossman R.B., and Reinsch T.G., 2002. Bulk density and linear extensibility. In: J.H. Dane and G.C. Topp, editors, Methods of soil analysis. Part 4. SSSA Book Ser. 5. SSSA, Madison, WI, 201-228. doi:10.2136/sssabookser5.4.c9

Haruna S.I., 2019. Influence of winter wheat on soil thermal properties of a Paleudalf. Int. Agroph., 33:389-395, https:// doi.org/10.31545/intagr/110850

Haruna S.I., and Nkongolo N.V., 2013. Variability of soil physical properties in a clay-loam soil and its implication on soil management practices. Int. Sch. Res. Notices. 418586, 1-8. http://dx.doi.org/10.1155/2013/418586

Haruna S.I., and Nkongolo N.V., 2014. Spatial and fractal characterization of soil chemical properties and nutrients across depths in a clay-loam soil. Commun. Soil Sci. Plant Anal., 45, 2305-2318, https://doi.org/10.1080/00103624.2014.932371

Haruna S.I., Anderson S.H., Nkongolo N.V., Reinbott T., and Zaibon S., 2017. Soil thermal properties influenced by perennial biofuel and cover crop management. Soil Sci. Soc. Am. J., 81, 1147-1156, https://doi.org/10.2136/sssaj2016.10.0345

Isaaks E.H., and Srivastava R.M., 1989. An introduction to applied geostatistics. Oxford University Press, Ney York, 561.

Kenneth F., 2003. Fractal geometry: mathematical foundations and applications. Wiley, 308-309.

Kerry R., and Oliver M.A., 2004. Average variograms to guide soil sampling. Int. J. Appl. Earth Obs. Geoinf., 5, 307-325. http://dx.doi.org/10.1016/j.jag.2004.07.005

Khan F., Hayat Z., Ahmed W., Ramzan M., Shah Z., Sharif M., Mian I.A., and Hanif M., 2013. Effect of slope position on physico-chemical properties of eroded soil. Soil Environ., 32, 22-28.

Kosmas C., Gerontidis S., and Marathianou M., 2000. The effects of land use change on soils and vegetation over various lithological formations on Lesvos (Greece). Catena, 40, 51-68, https://doi.org/10.1016/S0341-8162(99)00064-8

Lacasse S., and Nadim F., 1996. Uncertainties in characterizing soil properties. In: Shackleford C.D. P.P. Nelson, and M.J.S. Roth (eds.) Uncertainty in the geologic environment: from theory to practice. ASCE GSP, 58, 49-75.

Lee S.I., 2017. Correlation and spatial autocorrelation. In: Shekhar S., Xiong H., Zhou X. (eds.). Encyclopedia of GIS. Springer, Cham, https://doi.org/10.1007/978-3-319-17885-1_1524

Lipiec J., Usowicz B., and Ferrero A., 2007. Impact of soil compaction and wetness on thermal properties of sloping vineyard soil. Int. J. Heat Mass Transf., 50, 3837-3847, https://doi.org/10.1016/j.ijheatmasstransfer.2007.02.008
Longbottom T.L., Townsend-Small A., Owen L.A., and Murari M.K., 2014. Climatic and topographic controls on soil organic matter storage and dynamics in the Indian Himalaya: Potential carbon cycle-climate change feedback. Catena, 119, 125-135, https://doi.org/10.1016/j.catena. 2014.03.002

McBratney A.B., and Webster R., 1986. Choosing functions for semi-variograms of soil properties and fitting them to sampling estimates. J. Soil Sci., 37, 617-639., https://doi. org/10.1111/j.1365-2389.1986.tb00392.x

Mohanty B.P., and Mousil Z., 2000. Saturated hydraulic conductivity and soil water retention properties across a soil-slope transition. Water Resour. Res., 36, 3311-3324, https://doi.org/10.1029/2000WR900216

Mulla D.J., and McBratney A.B., 2002. Soil spatial variability. In: A.W. Warrick (eds.). Soil Physics Companion. CRC Press, Boca Raton, FL. USA, 343-373, https://doi. org/10.1201/9781420041651.ch9

Ochsner T.E., Horton R., and Ren T., 2001. A new perspective on soil thermal properties. Soil Sci. Soc. Am. J., 65, 16411647. doi:10.2136/sssaj2001.1641

Oliver M.A., 1987. Geostatistics and its application to soil science. Soil Use \& Management, 3, 8-20, https://doi. org/10.1111/j.1475-2743.1987.tb00703.x

Ozgoz E., 2009. Long-term conventional tillage effect on spatial variability of some soil physical properties. J. Sustain. Agric., 33, 142-160, https://doi.org/10.1080/10440040802395056

Oztas T., Koc A., and Comakli B., 2003. Changes in vegetation and soil properties along a slope on overgrazed and eroded rangelands. J. Arid Environ., 55, 93-100, https://doi. org/10.1016/S0140-1963(02)00267-7

Perfect E., and Kay B.D., 1995. Applications of fractals in soil and tillage research: A review. Soil Till. Res., 36, 1-20, https://doi.org/10.1016/0167-1987(96)81397-3

Robinson T.P., and Metternicht G., 2006. Testing the performance of spatial interpolation techniques for mapping soil properties. Comput. Electron. Agric., 50(2), 97-108. http:// dx.doi.org/10.1016/j.compag.2005.07.003

SAS Institute., 2013. SAS user's guide. Statistics. SAS Institute. Cary, NC. USA.

Schulte E.E., and Hopkins B.G., 1996. Estimation of soil organic matter by weight Loss-On Ignition. In: Magdoff F.R. M.R. Tabatabai, and E.A. Hanlon Jr. (eds.). Soil organic matter: analysis and interpretation. Special publication of Soil Sci. Soc. Am., Madison, WI, USA, 21-32 https://doi.org/10. 2136/sssaspecpub46.c3

Shukla M.K., 2014. Soil physics: An introduction. CRC Press, Boca Raton, FL, 215-233.

Sindelar M., Blanco-Canqui H., Jin V.L., and Ferguson R., 2019. Do cover crops and corn residue removal affect soil thermal properties? Soil Sci. Soc. Am. J., 83, 448-457, https://doi.org/10.2136/sssaj2018.06.0239.

Soil Survey Staff, Natural Resources Conservation Service, United States Department of Agriculture. Web Soil Survey. Available online at http://websoilsurvey.sc.egov.usda.gov/ (verified January 13, 2021).

Uhland R.E., 1950. Physical properties of soils as modified by crops and management. Soil Sci. Soc. Am. J., 14, 361-366, https://doi.org/10.2136/sssaj1950.036159950014000C0085x 
Usowicz B., Kossowski, J, and Baranowski P., 1996. Spatial variability of soil thermal properties in cultivated fields. Soil Till. Res., 39, 85-100, https://doi.org/10.1016/ S0167-1987(96)01038-0.

Usowicz B., 1999. Application of geostatistical analysis and fractal theory for the investigation of moisture dynamics in soil profile of cultivated field. Acta Agroph., 22, 229-243.

Usowicz B., Lukowski M.I., Rudiger C., Walker J.P., and Marczewski W., 2017. Thermal properties of soil in the Murrumbidgee River Catchment (Australia). Int. J. Heat Mass Transf., 115, 604-614, https://doi.org/10.1016/j. ijheatmasstransfer.2017.08.021
Usowicz B., and Lipiec J., 2021. Spatial variability of saturated hydraulic conductivity and its links with other soil properties at the regional scale. Sci. Rep., 11, 8293, https://doi. org/10.1038/s41598-021-86862-3

Yang P., Byrne J.M., and Yang M., 2016. Spatial variability of soil magnetic susceptibility, organic carbon and total nitrogen from farmland in northern China. Catena, 145, 92-98. http://dx.doi.org/10.1016/j.catena.2016.05.025

Zaibon S., Anderson S.H., Veum K.S., and Haruna S.I., 2019. Soil thermal properties affected by topsoil thickness in switchgrass and row crop management systems. Geoderma, 350, 93-100, https://doi.org/10.1016/j.geoderma.2019.05.005 